\title{
ФОРМУВАННЯ ЛІСОВОЇ ПІДСТИЛКИ В ДЕРЕВОСТАНАХ ЗА УЧАСТЮ МОДРИНИ ЄВРОПЕЙСЬКОЇ В УМОВАХ КРЕМЕНЕЦЬКОГО ГОРБОГІР'Я
}

\begin{abstract}
Досліджено формування лісової підстилки в 14-109-річних деревостанах за участю модрини європейської. У складі деревостанів частка модрини змінюється в межах 1-10 одиниць. Встановлено, що під наметом деревостанів за участю модрини європейської запас лісової підстилки в абсолютно сухому стані становить $0,30-1,96$ кг/м². У ії складі маса листя і хвої

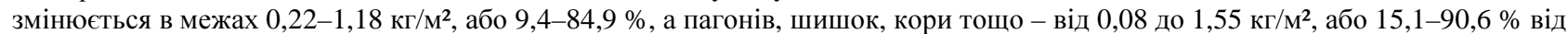
загальної їі маси. У модрини у віці молодняків розпочинається і продовжується в середньовікових деревостанів до 50-60 років інтенсивне відмирання пагонів та очищення стовбурів дерев від сучків. Воно призвело до збільшення у складі лісової підстилки маси пагонів і кори до 50-90\%. У чистих модринових деревостанах нагромаджується більший запас лісової підстилки, ніж у мішаних. У молодняків запас лісової підстилки в чистому модриновому деревостані перевищує мішані на 2,188,6 \%. У середньовікових, стиглих і перестиглих деревостанів такі відмінності становлять 4,7-75,4 \%. Показано, що лісостани характеризуються різним варіюванням маси лісової підстилки загалом чи ії фракцій у межах деревостану. Коефіцієнт варіації маси лісової в деревостанах виявився в основному середнім і рідше слабким $(V=6,1-20,5 \%)$. Поряд 3 цим значно зростає варіювання фракцій лісової підстилки. Так, варіювання маси хвої і листя змінюється в межах 6,8-33,1\%, а фракції пагонів, шишок, кори тощо - 6,1-42,9\%.
\end{abstract}

Ключові слова: модринові лісостани; лісова підстилка; опад; лісівничо-таксаційні показники; модрина європейська.

Вступ. Лісова підстилка є одним із компонентів лісостанів, яка відіграє низку різних важливих функцій (Hordiienko \& Karpenko, 1996; Krylov, 2013; Pylypenko, et al., 2010; Svyrydenko, Babich \& Kyrychok, 2008; Seheda, 2017). Вона утворюється в процесі формування деревостанів унаслідок опадання відмерлих частин деревних і чагарникових видів: листя і хвої, пагонів, плодів, кори тощо. Залежно від породного складу деревостанів формуються різні типи лісових підстилок, які відрізняються потужністю та швидкістю мінералізації (Lukaniuk, 2013). Лісова підстилка істотно впливає на водний режим грунтів (Kovalenko, 1968; Krylov, 2013; Pylypenko, et al., 2010; Svyrydenko, Babich \& Kyrychok, 2008). Вона затримує і утримує значну частину опадів, запобігає виникненню поверхневого стоку та випаровуванню води із грунту. Очевидно не менша ії терморегуляційна роль для лісових грунтів.

Лісова підстилка має важливе значення для кругообігу елементів мінерального живлення. У процесі іï розкладання та мінералізації верхні горизонти грунту збагачуються поживними речовинами (Hordiienko \& Karpenko, 1996; Lukaniuk, 2013; Svyrydenko, Babich \& Kyrychok, 2008). Найбільше це питання вивчено у видів роду Tilia L. Так, у листках липи дрібнолистої виявлено 14 , у липи широколистої і європейської - 21 , у липи американської - 16 елементів мінерального живлення
(Lukaniuk, 2013). Найбільше вони нагромаджують калію (4700-10500), кальцію (5800-25681) і магнію (763$15230 \mathrm{мг/кг).}$

Опад деревних видів у процесі мінералізації також призводить до зміни $\mathrm{pH}$ грунтового розчину: хвойних спричиняє формування кислого середовища, а листяних - лужного.

Під наметом лісостанів можуть нагромаджуватись десятки тонн на гектарі лісової підстилки. За даними М. І. Гордієнка, В. I. Карпенка (Hordiienko \& Karpenko, 1996), у свіжих грабових дібровах її запас досягає 2328 т/га. У молодняках природного походження на покинутих сільськогосподарських землях іії маса змінюється від 9,9 до 15,4 т/га і зростає зі збільшенням частки сосни звичайної у складі березово-соснових деревостанів (Zaika, Krynytskyi \& Ivanytskyi, 2013). Вплив модрини європейської на формування лісової підстилки в деревостанах за іï участі залишається не дослідженим.

Об'єктом дослідження слугували деревостани за участю модрини європейської в умовах Кременецького горбогір'я.

Предмет дослідження - формування лісової підстилки в деревостанах різного віку за участю модрини європейської в різних лісорослинних умовах.

Мета дослідження - встановити особливості формування лісової підстилки в деревостанах за участю

\section{Інформація про авторів:}

Керімов Ельхан Ілхамович, викладач, кафедра лісівництва. Email: elhan26@rambler.ru

Заїка Володимир Костянтинович, д-р біол. наук, професор, кафедра лісівництва. Email: vkzaika@ukr.net

Цитування за Дсту: Керімов Е. І., Заїка В. К. Формування лісової підстилки в деревостанах за участю модрини європейської в умовах Кременецького горбогір'я. Науковий вісник НлтУ України. 2019, т. 29, № 1. С. 30-33.

Citation APA: Kerimov, E. I., \& Zaika, V. K. (2019). Formation of the Forest Floor in the Stands with the Participation of European Larch in the Conditions of the Kremenets Hill Area. Scientific Bulletin of UNFU, 29(1), 30-33. https://doi.org/10.15421/40290105 
модрини європейської залежно від їх лісівничо-таксаційних показників.

Дослідження проводили в деревостанах за участю модрини європейської віком 14-109 років, які ростуть в умовах від бідних суборів до свіжих і вологих грудів Кременецького горбогір'я. Частка модрини у їх складі становить від 1-ї до 10-ти одиниць. Серед них переважають деревостани з часткою модрини 5-8 одиниць. Вони ростуть за II - I ${ }^{\mathrm{d}}$ класами бонітету (Zaika, Kerimov \& Ivanytskyi, 2016).

Для дослідження лісової підстилки на дослідних ділянках закладали по п'ять рівномірно розташованих на площі площадок розміром $50 \times 50 \mathrm{~cm}$ (Grishina \& Samoilova, 1971). 3 них збирали лісову підстилку, яку розділювали на дві фракції - листя і хвоя та пагони, шишки, кора, плоди тощо. Отримані проби висушували до абсолютно сухого стану і зважували.

Табл. 1. Маса лісової підстилки в лісостанах з різною

\begin{tabular}{|c|c|}
\hline $\begin{array}{c}\text { № пр. } \\
\text { пл. }\end{array}$ & Склад деревостану \\
\hline 13 & 10Мдє+Клг, Кляс, Акб, Ос \\
\hline 15 & $9 \mathrm{M} д \epsilon 1 \mathrm{C} 3$ \\
\hline 14 & $8 \mathrm{Mдє2С} 3+$ Чш \\
\hline 11 & 4Мдг3Кля1Ясз1Дч1Вхч+Дз, Взг, Гз, Кляс, Бп \\
\hline 17 & 10Мдє+Дз, Ясз, Лпд, Клг, Гз \\
\hline 8 & 7Мдє3Ясз+Дз, Гз, Клг, Взг, Лпд \\
\hline 18 & 6Мдє3Дз1Клг+Кля, Лпд, Взг, Гз, Бп \\
\hline 19 & 6Мдє2Бп1Дз 1Гз+Вхч, Клг, Лпд \\
\hline 10 & 8Дч1Мдє1Бкл+Кля, Ясз, Гз, Взг, Лпд \\
\hline 5 & 2Мдє2Ясз2Дч2Клг1Дз1Гз+Взг, Лпд \\
\hline 2 & 9Мє1Кля+Клг, Бп, Гз \\
\hline 7 & 3МдєЗГз1Дз1Ясз1Дч1Взг+Клг, Лпд, Бп \\
\hline 12 & 5Мдє4Дз1Гз+Клг, Кля, Лпд \\
\hline 1 & 5Мє2Ясз1Дз1Кля1Бха+Клг, Взг, Гз \\
\hline 9 & 7Мдє1Ялє1Ясз1Клг+Взг, Лпд, Гз \\
\hline 4 & 6Мдє3Дз1Взг+Кля, Гз \\
\hline 16 & 7Мдє2Ясз1 ДзБкл+КлгКляВзг \\
\hline 3 & $8 \mathrm{M} д є 1$ Дз, Ясз1Гз+Клг \\
\hline
\end{tabular}

3 табл. 1. видно, що загальна маса лісової підстилки під наметом дослідних деревостанів змінюється в межах

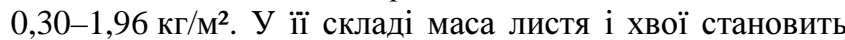

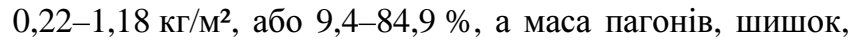

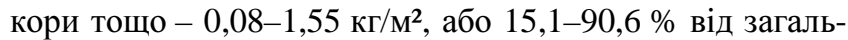
ної ії маси. Встановлено значну мінливість деревостанів за загальною масою лісової підстилки та ії̈ компонентів. Такі відмінності зумовлені складом деревостанів, віком,
Результати дослідження. Лісівничо-таксаційні показники дослідних деревостанів та особливості їх формування наведено в нашій роботі (Zaika, Kerimov \& Ivanytskyi, 2016). Досліджено, що в умовах Кременецького горбогір'я модрина європейська в сугрудах і грудах формує складні високопродуктивні деревостани 3 запасом деревини до $700 \mathrm{~m}^{3} /$ га. Ї̈ї бонітет змінюється в межах $\mathrm{I}^{\mathrm{a}}-\mathrm{I}^{\mathrm{e}}$. Істотним конкурентом модрини європейської у відносно багатих і багатих типах лісорослинних умов є ясен звичайний і дуб червоний. У суборах за інтенсивністю росту сосна звичайна не поступається модрині європейській. У ялиново-модринових деревостанах спостерігається істотне відставання ялини європейської за інтенсивністю росту від модрини вже в молодому віці.

Результати нашого дослідження формування лісової підстилки наведено в табл. 1.

\section{асткою модрини європейської (абсолютно сухий стан)}

\begin{tabular}{|c|c|c|c|}
\hline \multirow{2}{*}{ Вік, } & \multicolumn{3}{|c|}{ Маса підстилки, кг/м² } \\
\hline & листя і хвоя & пагони, шишки, кора тощо & разом \\
\hline 14 & $1,18^{ \pm 0,06}$ & $0,21^{ \pm 0,02}$ & $1,40^{ \pm 0,06}$ \\
\hline 25 & $0,22^{ \pm 0,02}$ & $0,08^{ \pm 0,01}$ & $0,30^{ \pm 0,03}$ \\
\hline 29 & $0,70^{ \pm 0,03}$ & $0,67^{ \pm 0,06}$ & $1,37^{ \pm 0,07}$ \\
\hline 31 & $0,43^{ \pm 0,06}$ & $0,23^{ \pm 0,05}$ & $0,66^{ \pm 0,04}$ \\
\hline 50 & $0,16^{ \pm 0,01}$ & $1,55^{ \pm 0,04}$ & $1,71^{ \pm 0,05}$ \\
\hline 56 & $0,30^{ \pm 0,02}$ & $0,88^{ \pm 0,06}$ & $1,49^{ \pm 0,04}$ \\
\hline 43 & $0,97^{ \pm 0,04}$ & $0,66^{ \pm 0,06}$ & $1,63^{ \pm 0,06}$ \\
\hline 50 & $0,49^{ \pm 0,07}$ & $0,75^{ \pm 0,05}$ & $1,24^{ \pm 0,04}$ \\
\hline 46 & $0,82^{ \pm 0,06}$ & $0,24^{ \pm 0,04}$ & $1,05^{ \pm 0,03}$ \\
\hline 51 & $0,66^{ \pm 0,05}$ & $0,46^{ \pm 0,06}$ & $1,12^{ \pm 0,04}$ \\
\hline 52 & $0,46^{ \pm 0,04}$ & $0,81^{ \pm 0,08}$ & $1,28^{ \pm 0,09}$ \\
\hline 52 & $0,27^{ \pm 0,03}$ & $0,15^{ \pm 0,04}$ & $0,42^{ \pm 0,03}$ \\
\hline 53 & $0,45^{ \pm 0,01}$ & $0,34^{ \pm 0,03}$ & $0,79^{ \pm 0,03}$ \\
\hline 58 & $0,41^{ \pm 0,04}$ & $0,42^{ \pm 0,01}$ & $0,83^{ \pm 0,04}$ \\
\hline 60 & $0,63^{ \pm 0,07}$ & $1,33^{ \pm 0,05}$ & $1,96^{ \pm 0,05}$ \\
\hline 84 & $1,05^{ \pm 0,07}$ & $0,20^{ \pm 0,03}$ & $1,25^{ \pm 0,05}$ \\
\hline 101 & $0,78^{ \pm 0,04}$ & $0,31^{ \pm 0,01}$ & $1,09^{ \pm 0,05}$ \\
\hline 109 & $0,35^{ \pm 0,02}$ & $0,23^{ \pm 0,03}$ & $0,59^{ \pm 0,03}$ \\
\hline
\end{tabular}

повнотою та особливостями їх формування. Серед молодняків загальна маса лісової підстилки становить

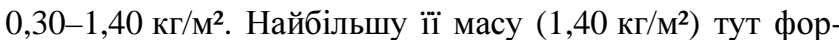
мує 14-річний модриновий деревостан зі складом 10Мдє+КлгКля АкбОс і густотою 4525 екз./га. Відносно нього під наметом інших деревостанів цієї вікової групи маса лісової підстилки виявилась на 2,1-88,6\% $\left(t_{\phi}=0,33-10,06 ; t_{05}=2,26\right)$ меншою (табл. 2).

Табл. 2. Достовірність відмінностей (t-критерій Стьюдента) маси лісової підстилки в деревостанах за участю модрини європейської та її варіювання

\begin{tabular}{|c|c|c|c|c|c|c|c|c|c|}
\hline \multirow{2}{*}{ № пр. пл. } & \multicolumn{3}{|c}{ Листя і хвоя } & \multicolumn{2}{c|}{ Пагони, шишки, кора тощо } & \multicolumn{3}{c|}{ Разом } \\
\cline { 2 - 10 } & $t_{\phi}$ & $\%$ & $V, \%$ & $t_{\phi}$ & $\%$ & $V, \%$ & $t_{\phi}$ & $\%$ & $V, \%$ \\
\hline 13 & 0,00 & 100,0 & 10,6 & 0,00 & 100,0 & 21,5 & 0,00 & 100,0 & 8,8 \\
\hline 15 & 15,18 & 18,6 & 18,5 & 5,81 & 38,1 & 35,0 & 2,50 & 21,4 & 20,5 \\
\hline 14 & 7,16 & 59,3 & 11,1 & 7,27 & 319,0 & 19,6 & 0,33 & 97,9 & 10,9 \\
\hline 11 & 8,84 & 36,4 & 29,7 & 0,37 & 109,5 & 42,9 & 10,06 & 47,1 & 12,0 \\
\hline 17 & 0,00 & 100,0 & 13,4 & 0,00 & 100,0 & 6,1 & 0,00 & 100,0 & 6,5 \\
\hline 8 & 6,26 & 187,5 & 10,9 & 9,29 & 56,8 & 19,6 & 3,44 & 87,1 & 12,7 \\
\hline 18 & 2,02 & 606,3 & 14,7 & 12,34 & 42,6 & 21,2 & 1,02 & 95,3 & 8,0 \\
\hline 19 & 4,67 & 306,3 & 33,1 & 12,49 & 48,4 & 16,1 & 7,34 & 72,5 & 7,2 \\
\hline 10 & 10,85 & 512,5 & 16,4 & 23,16 & 15,5 & 42,5 & 11,32 & 61,4 & 9,6 \\
\hline 5 & 9,81 & 412,5 & 21,8 & 15,12 & 29,7 & 28,9 & 9,21 & 65,5 & 9,0 \\
\hline 2 & 7,28 & 287,5 & 18,0 & 8,27 & 52,3 & 24,7 & 4,18 & 74,9 & 15,6 \\
\hline 7 & 3,48 & 168,8 & 28,5 & 24,75 & 9,7 & 33,4 & 22,12 & 24,6 & 15,9 \\
\hline 12 & 20,51 & 281,3 & 6,8 & 24,20 & 21,9 & 18,2 & 15,78 & 46,2 & 8,9 \\
\hline 1 & 6,06 & 256,3 & 22,3 & 27,41 & 27,1 & 6,6 & 13,74 & 48,5 & 11,9 \\
\hline 9 & 6,65 & 393,8 & 23,5 & 3,44 & 85,8 & 8,2 & 3,54 & 114,6 & 6,1 \\
\hline 4 & 12,59 & 656,3 & 15,6 & 27,00 & 12,9 & 35,4 & 6,51 & 73,1 & 8,8 \\
\hline 16 & 15,04 & 487,5 & 11,4 & 30,07 & 20,0 & 8,0 & 8,77 & 63,7 & 10,4 \\
\hline 3 & 8,50 & 218,8 & 13,4 & 26,40 & 14,8 & 25,8 & 19,21 & 34,5 & 6,7 \\
\hline
\end{tabular}

Примітка: діл. 13 є контролем для молодняків, а 17 - для середньовікових, стиглих і перестиглих деревостанів. 
У складі лісової підстилки фракції сформувались по-різному. Маса листя і хвої у її складі в молодняків становить 51,1-84,9\%, а пагонів, кори, шишок тощо $15,1-48,9 \%$. На діл. 13 у найгустішому деревостані маса хвої і листя у складі лісової підстилки є найбільшою

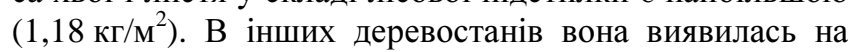
$18,6-59,3 \%\left(t_{\phi}=7,16-15,18 ; t_{05}=2,26\right)$ нижчою. Нагромадження пагонів, кори, плодів, шишок тощо в складі лісової підстилки залежить від інтенсивності очищення дерев від сучків, що посилюється під час формування деревостанів. На діл. 15 маса цієї фракції становила всього $38,1 \%\left(t_{\phi}=5,81\right)$ відносно контролю (діл. 13$)$, а на діл. 11 і 14 перевищує його на 9,5-219,0\%.

Середньовікові, стиглі і перестиглі деревостани також характеризуються великою мінливістю нагромадження лісової підстилки (див. табл. 1). У цих деревостанів її маса змінюється в межах 0,42-1,96 кг/м², а відмінності з контролем (діл. 17) становлять 4,7-75,4\% $\left(t_{\phi}=1,02-22,12\right)$. Необхідно відзначити деревостани на пр. пл. $2,4,8,9,17,18,19$ з високим нагромадженням лісової підстилки. Частка модрини у їх складі становить 6-10 одиниць, а повнота - 13,9-48,2 м²/га. Серед них тільки на діл. 9 маса лісової підстилки істотно (на $14,6 \%)\left(t_{\phi}=3,54\right)$ перевищувала контроль. Низьким нагромадженням лісової підстилки $(0,42-0,83$ кг/м²) характеризуються деревостани на діл. $1,3,7,12$. Вони істотно відстають від контролю (на 51,5-75,4 \%) $\left(t_{\phi}=13,74\right.$ $22,12)$ - див. табл. 2. Розподіл лісової підстилки на фракції показав на велику мінливість ії компонентів. Загалом у середньовікових, стиглих і перестиглих деревостанів вміст листя і хвої у лісовій підстилці становить 9,4-84,0 \%, а пагонів, шишок, кори тощо змінюється в межах від 22,9 до 90,6 \%. У модриновому деревостані на пр. пл. 17 унаслідок інтенсифікації процесів очищення дерев від сучків у фракціях лісової підстилки переважають пагони, кора, шишки тощо (рисунок.)

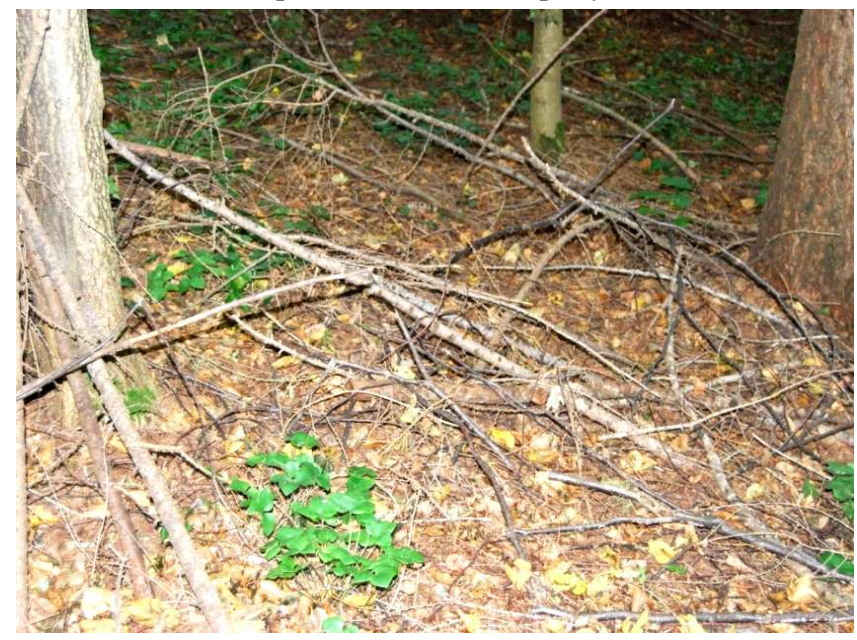

Рисунок. Лісова підстилка під наметом 50-річного модринового деревостану на пр. пл. 17

Загалом маса хвої і листя в лісовій підстилці контрольного середньовікового деревостану (пр. пл. 17) виявилась найменшою. Дослідні середньовікові, стиглі і перестиглі деревостани за цим показником перевищують контроль в $1,7-6,6$ раза $\left(t_{\phi}=2,02-20,51\right)$. Найбільшою масою хвої і листя характеризується лісова підстилка в деревостанах на пр. пл. $4,10,16,18$, де вона перевищує контрольний деревостан у 4,9-6,6 раза. Водночас контрольний деревостан виділяється масою паго- нів, кори, шишок тощо у лісовій підстилці. Маса цієї фракції на контролі істотно перевищує інші деревостани на $14,2-90,3 \%\left(t_{\phi}=3,44-30,07\right)$.

Лісостани характеризуються різним варіюванням маси лісової підстилки загалом чи ії фракцій в межах деревостану. Коефіцієнт варіації маси лісової в деревостанах виявився в основному середнім і рідше слабким $(V=6,1-20,5 \%)$. Поряд 3 цим значно зростає варіювання фракцій лісової підстилки. Так, коефіцієнт варіації маси хвої і листя змінюється в межах 6,8-33,1 \%, а фракції пагонів, шишок, кори тощо - 6,1-42,9 \%.

Наші дослідження показують, що в модрини інтенсивне очищення дерев від сучків розпочинається у молодняків і продовжується у середньовікових деревостанах. Інтенсивність цього процесу залежить від густоти створення лісових культур та розвитку внутрішньовидових i міжвидових конкурентних взаємовідносин. Наприклад, на діл. 13, де ширина міжрядь становить 2,5 м у віці 14 років, лісова підстилка формується переважно за рахунок хвої і листя. Після 20-25-річного віку у модрини посилюються процеси очищення дерев від сучків та залишаються інтенсивними ще у 50-60-річному віці. Модрина належить до найбільш світлолюбних видів серед деревних порід. Світловий компенсаційний пункт у неї вже спостерігається за інтенсивності світла близько 6 тис. лк (Veretennikov, 1987).

Отже, формування маси лісової підстилки під наметом дослідних деревостанів найбільше залежить від інтенсивності процесів очищення стовбурів дерев від сучків, повноти та частки модрини європейської у складі деревостану.

\section{Висновки:}

1. Під наметом деревостанів за участю модрини європейської запас лісової підстилки становить 0,30 1,96 кг/м². У її складі маса листя і хвої змінюється в ме-

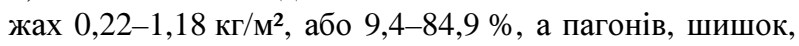

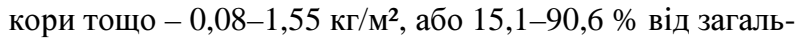
ної іï маси.

2. У модрини у віці молодняків розпочинається і продовжується в середньовікових деревостанів до 50-60 років інтенсивне відмирання пагонів та очищення стовбурів дерев від сучків. Воно призвело до збільшення у складі лісової підстилки маси пагонів, шишок, кори тощо до 50-90\%.

\section{Перелік використаних джерел}

Grishina, L. A., \& Samoilova, E. M. (1971). Uchet biomassy i khimicheskii analiz rastenii. Moscow, 99 p. [In Russian].

Hordiienko, M. I., \& Karpenko, V. I. (1996). Lypa dribnolysta i kultury z yii uchastiu. Kyiv: Silhosposvita, 224 p. [In Ukrainian].

Kovalenko, A. I. (1968). Pochvozashhitnye svoistva i rost dubrav "Chernogo lesa" na chernozemnykh pochvakh. Candidate Dissertation for Agricultural Sciences (28.02.68 - Forest crops and Phytomelioration). Kyiv, 283 p. [In Russian].

Krylov, Ya. I. (2013). Melioratyvna kharakterystyka lisovoi pidstylky dubovykh protyeroziinykh nasadzhen. Scientific Bulletin of UNFU, 23(17), 43-48. [In Ukrainian].

Lukaniuk, M. I. (2013). Farmakohnostychne doslidzhennia roslyn ro$\mathrm{du}$ Tilia L. Abstract of Doctoral for Pharmaceutical Sciences (15.00.02 - Pharmaceutical Chemistry and Pharmacognosy). Kharkiv, 24 p. [In Ukrainian].

Pylypenko, O. I., Yukhnovskyi, V. Yu., Dudarets, S. M., \& Maliuha, V. M. (2010). Lisovi melioratsii. Kyiv: Ahrarna osvita, 282 p. [In Ukrainian].

Seheda, Yu. Yu. (2017). Morphological and fractional composition and stocks of oak forest litter in the forest fund of smila state 
forestry enterprise. Scientific Bulletin of UNFU, 27(4), 75-77. https://doi.org/10.15421/40270416

Svyrydenko, V. Ye., Babich, O. H., \& Kyrychok, L. S. (2008). Lisivnytstvo. Kyiv: Aristei, 544 p. [In Ukrainian].

Veretennikov, A. V. (1987). Fiziologiia rastenii s osnovami biokhimii. Voronezh: Izd-vo VGU, 256 p. [In Russian].

Zaika, V. K., Kerimov, E. I., \& Ivanytskyi, R. S. (2016). Poshyrennia ta rist modryny yevropeiskoi v umovakh Kremenetskoho horbohi- ria. Proceedings of the Forestry Academy of Sciences of Ukraine, 14, 45-51. Lviv: TzOV "Kamula". [In Ukrainian].

Zaika, V. K., Krynytskyi, H. T., \& Ivanytskyi, R. S. (2013). Pryrodne zalisennia ta lisivnycho-ekolohichni i morfofiziolohichni osoblyvosti formuvannia lisostaniv na pokynutykh silskohospodarskykh zemliakh Pivnichno-zakhidnoho Podillia. Proceedings of the Forestry Academy of Sciences of Ukraine, 11, 41-50. Lviv: RVV NLTU Ukrainy. [In Ukrainian].

E. I. Kerimov' ${ }^{1}$, V. K. Zaika ${ }^{2}$

1 Kremenetskiy Forestry College, Bilokrynytsya, Ukraine 2 Ukrainian National Forestry University, Lviv, Ukraine

\section{FORMATION OF THE FOREST FLOOR IN THE STANDS WITH THE PARTICIPATION OF EUROPEAN LARCH IN THE CONDITIONS OF THE KREMENETS HILL AREA}

The study was conducted to determine the role of European larch in the formation of forest floor in the stands of different ages, species composition, site conditions and other silvicultural indexes. Investigated was the formation of forest floor in 14-109-year-old stands with the participation of European larch, growing in fairly infertile pine site types, fairly fertile site types, and fertile site types. In the composition of the stands, the larch share varies within 1-10 units, the density is $12.6-48.2 \mathrm{~m}^{2} /$ ha, the growing stock is $73-$ $700 \mathrm{~m}^{3} / \mathrm{ha}$. It was found that the forest floor stock, under the canopy of forest stands with the participation of larch, in an absolutely dry condition is $0.30-1.96 \mathrm{~kg} / \mathrm{m}$. The mass of leaves and needles ranges from 0.22 to $1.18 \mathrm{~kg} / \mathrm{m}^{2}$, or $9.4-84.9 \%$, and shoots, cones, bark, etc. - from 0.08 to $1.55 \mathrm{~kg} / \mathrm{m}^{2}$, or $15.1-90.6 \%$ of its total mass. Larch trees experience intense dying of shoots and self-pruning, which begins in young stands and continues in middle-aged stands up to 50-60 years. This leads to an increase in the shoots and bark share in the composition of the forest floor mass up to 50-90\%. In pure larch stands, a larger volume of forest litter is accumulated than in mixed ones.In young stands, the volume of forest floor in pure larch stands exceeds that of mixed stands by $2.1-$ $88.6 \%$. In middle-aged, mature and overmature stands, these differences make up 4.7-75.4\%. It is shown that different forest stands are characterized by varying mass of the forest floor as a whole or its factions within the stand. With increasing soil nutrient status, an increase in the accumulation of forest litter is observed. At the same time, no connection was traced between the mass of the forest litter and the age of the stands. The coefficient of variation of the forest floor mass in the stands was mostly mean and less rarely weak $(\mathrm{V}=6.1-20.5 \%)$. Along with this, the variation of the forest floor fraction increases significantly. The coefficient of variation of the mass of needles and leaves varies within $6.8-33.1 \%$, and the fraction of shoots, cones, bark, etc. $-6.1-42.9 \%$. It is concluded that the formation of the forest floor mass under the canopy of the study stands is most dependent on the intensity of the pruning processes, the density and share of European larch in the composition of the stands.

Keywords: larch forests; forest floor; litter; silvicultural indexes; European larch. 